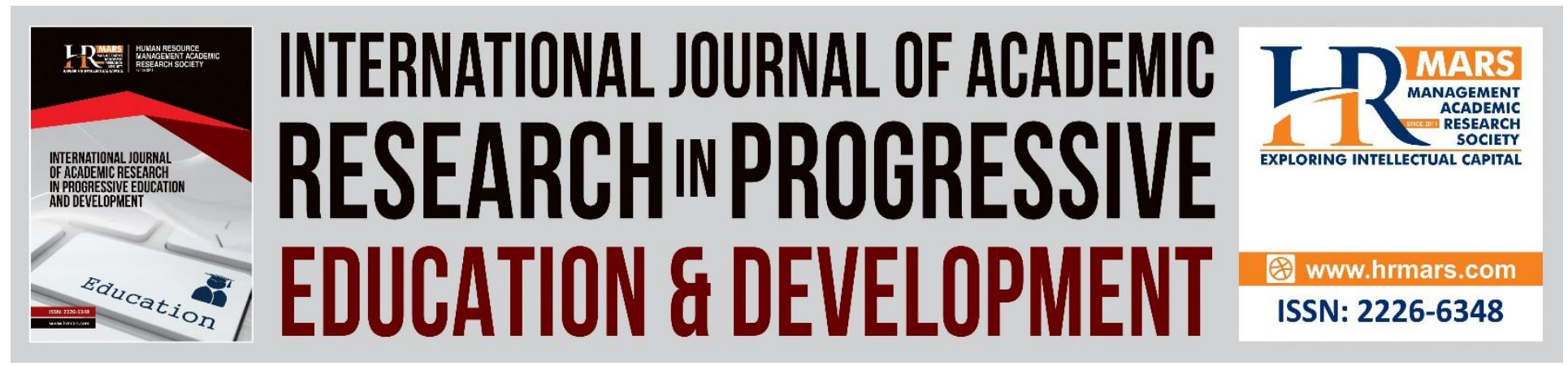

\title{
Fundamental Problems Faced by the Management of Private Secondary Schools in Enugu Metropolis
}

Blessing Anukaenyi, Prof. Modebelu Melody, Lauretta E. MAMA

To Link this Article: http://dx.doi.org/10.6007/IJARPED/v7-i4/4852

DOI: $10.6007 /$ IJARPED/v7-i4/4852

Received: 17 Oct 2018, Revised: 11 Nov 2018, Accepted: 03 Dec 2018

Published Online: 12 Dec 2018

In-Text Citation: (Anukaenyi, Melody, \& Mama, 2018)

To Cite this Article: Anukaenyi, B., Melody, M., \& Mama, L. E. (2018). Fundamental Problems Faced by the Management of Private Secondary Schools in Enugu Metropolis. International Journal of Academic Research in Progressive Education and Development, 7(4), 267-279.

Copyright: (C) 2018 The Author(s)

Published by Human Resource Management Academic Research Society (www.hrmars.com)

This article is published under the Creative Commons Attribution (CC BY 4.0) license. Anyone may reproduce, distribute, translate and create derivative works of this article (for both commercial and non-commercial purposes), subject to full attribution to the original publication and authors. The full terms of this license may be seen

at: http://creativecommons.org/licences/by/4.0/legalcode

Vol. 7, No. 4, 2018, Pg. 267 - 279

http://hrmars.com/index.php/pages/detail/IJARPED

JOURNAL HOMEPAGE

Full Terms \& Conditions of access and use can be found at http://hrmars.com/index.php/pages/detail/publication-ethics 


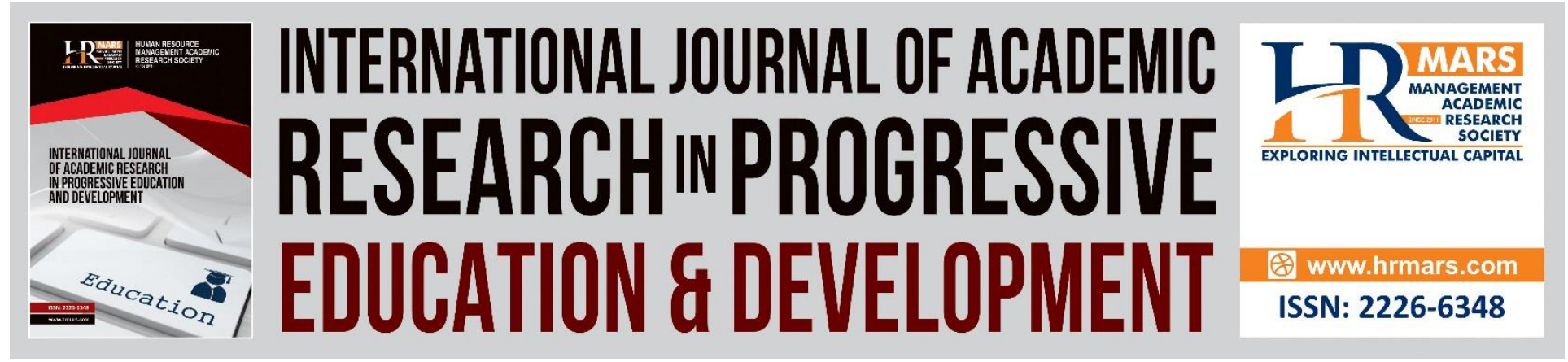

\title{
Fundamental Problems Faced by the Management of Private Secondary Schools in Enugu Metropolis
}

\author{
Anukaenyi, Blessing \\ Department of Arts and Social Science Education \\ Godfrey Okoye University, Enugu \\ Email: blessinganukaenyi@gmail.com \\ Prof. Modebelu Melody \\ Department of Education Management \\ Michael Okpara University of Agriculture, Umudike Umuahia \\ Email:melodyne@gmail.com \\ Lauretta E. MAMA \\ Department of Curriculum Studies, \\ Enugu State College of Education (Tech.) Enugu
}

\begin{abstract}
This study is an examination of the fundamental problems faced by the management of private secondary schools in Enugu metropolis. The study specifically seeks to; determine whether funding constitutes a problem to the management of private secondary schools in Enugu Metropolis, and to determine whether the lack of physical facilities contribute to the problems of the management of private secondary schools in Enugu metropolis. The population for the study comprised of the two hundred and fifty (250) approved private secondary schools presently in Enugu metropolis with about five thousand and thirty (5030) secondary school teachers and one hundred and four (104) principals currently serving in all private secondary schools; stratified sampling procedures were used in selecting the required sample for this study, purposive sampling was used in this study in selecting ten schools. Simple random sampling using random number tables was then used to select 500 teachers and 10 principals from the schools. As a result, at Enugu east 4 secondary schools comprising of 190 teachers and 4 principals were selected; at Enugu north 3 secondary schools comprising of 165 teachers and 3 principals were selected; at Enugu south, 3 secondary schools 145 teachers and 3 principals were selected. Thus a total of 10 secondary schools, 500 teachers and 10 principals were sampled. Questionnaire which was validated by experts was the instrument used for data collection. Mean scores, grand mean, and standard deviation were used to answer the research questions while the hypotheses were tested
\end{abstract}


INTERNATIONAL JOURNAL OF ACADEMIC RESEARCH IN PROGRESSIVE EDUCATION AND DEVELOPMENT

Vol. 7, No. 4, 2018, E-ISSN: 2226-6348 ๑ 2018 HRMARS

using t-test statistics at 0.05 level of significance and appropriate degree of freedom. The study revealed that lack of funds in private secondary schools contribute immensely to the failure of managers, also lack of conducive learning environment due to inadequate physical facilities constitute problems to the administrators in Enugu metropolis, this is due to the increasing population of children in the metropolis and also parents tend to believe that their children are not properly educated in public schools. The study concluded that the inadequate funding of private schools must be handled in order to prevent collapse of the institution and the private schools going out of business, also the essential physical facilities needed for the proper and effective running of private secondary schools in Enugu metropolis must be acquired and properly installed for business to continue.

Keywords: Private secondary schools, Inadequate Funding, Lack of Physical facilities, Management.

\section{Introduction}

The debate for privatization of education has become a global issue in recent years. The debate has come in different forms with different interpretations such as deregulation; increasing the role of parents in the financing of education and private ownership of the funding and management of schools and the private investment with focus on cost recovery. The heavy burden of ever-increasing government expenditure on higher education in both developed and developing nations no doubt necessitated the debate.

Private education is a reality and has been growing around the world together with globalization. Even in the centrally planned countries of Eastern Europe, France and the egalitarian Germany; former Soviet Union, China, Mongolia and Tanzania; where the culture of private ownership of educational institutions was alien; the wind of globalization and market reforms have reverted the situation.

Education has remained a social process in capacity building and maintenance of society for decades, as well as a weapon for acquiring skills, relevant knowledge and habits for surviving in the changing world (Adepoju and Fabiyi 2007). According to Adesina (2011), education is a major force in economic, intellectual, social and cultural empowerment. He goes on to say that education has the capacity to bring about character and attitudinal change, as well as reshape human potential for desired development. Also, against the background of the apparent inertia of government apparatus in providing quality education for the teeming population, it becomes expedient that private initiative in education be facilitated and encouraged.

In Nigeria, the trend has been that of the private sector gradually taking over the primary and secondary sub-sectors of the education industry. In most parts of South-West, South-East and South-South of the country, the number of privately owned pre-primary, primary and post primary educational institutions have grown exceedingly and their enrolment figures have far exceeded enrolment in public schools. But these private schools also face certain underlying challenges which most at times are held in high secrecy by top management in order not to dent the public image of the school. These challenges most times are fundamental, and may include the following; lack of funds, lack of physical facilities, bankruptcy and liquidity. As the privatisation of primary and secondary schools is global, so also the inherent fundamental problems and challenges faced by the management of these institutions are global. 
Vol. 7, No. 4, 2018, E-ISSN: 2226-6348 ๑ 2018 HRMARS

In Enugu metropolis, there exist a wide range and variety of private secondary schools, of which taking a glance at such schools, one might deem the schools to be a problem free schools, maybe due to the colourful uniforms, mighty school buildings, and adverts posed by the schools. But it is pertinent to know that every institution no matter how great, faces challenges once in a while, which can deter the activities and functions of the institution. Therefore this study seeks to examine the fundamental problems faced by the management of private secondary schools in Enugu metropolis.

\section{Objectives of the Study}

Specifically, the study seeks to:-

1. Determine whether funding constitutes a problem to the management of private secondary schools in Enugu Metropolis.

2. Determine whether the lack of physical facilities contribute to the problems of the management of private secondary schools in Enugu metropolis.

\section{Literature Review}

\section{Concept of Financial Management of Private Secondary Schools.}

Availability of funds to Private school owners is important. Most Private Schools are small in size, lacking teaching equipment and facilities and trapped in make shifts house or rented accommodation. Little Patronages, astronomical costs of accommodation retard their ability to acquire education specific environment, equipment, quality teachers, all necessary to meet set standards for the operation of schools in the state or even elsewhere.

Banks hardly do business with small size schools compounding their problem in accessing loans facility (Odeleye, Oyelamin \& Abike, 2012). Government of Enugu State would perhaps make possession of a given sum of funds and facility guarantee from a commercial bank, preconditions for licencing a school.

\section{Problem of Funding}

Funding has always been seen as one of the problems that face proper management of private schools in Enugu Metropolis. It has been described as one of the most serious drawbacks in particular. For any organization or society to function well, it must be financially viable. This is because finance is required for the establishment of infrastructure equipment. Salaries etc. most of our private schools are poorly equipped, poorly accommodated and poorly maintained, these school heads cannot perform their best in such situation. Pupils and students cannot learn effectively when the laboratories are not equipped. Even the little money available in schools, the school administrators have tried their best to source for money for minor expense. Adesina (1990) indicated that, the success of any school depends upon the resources available to it. Money is very important in this respect because by it all other vital element in the school can be obtained such as school building, purchase of equipment, payment of teacher's salaries and allowances and running expenses.

The above definition is of the view that proper management cannot be given a pride of place if the finance needed for the running of administrative activities is not available. Inadequate finance generates Laisser-faire, nonchalant and lack of co-operation among the staff hence makes it difficult for the organizational goal to be achieved. Whatever one intends to do whether 
INTERNATIONAL JOURNAL OF ACADEMIC RESEARCH IN PROGRESSIVE EDUCATION AND DEVELOPMENT

Vol. 7, No. 4, 2018, E-ISSN: 2226-6348 ๑ 2018 HRMARS

education or business irrespective of the level he proposed operating. For him to accomplish such intention finance must be prioritized.

In this study, the term financial state refers to the process of planning, mobilizing, acquiring, utilizing and control of financial resources. Moshin (1999) defines finance for education as the science and practice of raising and expending of revenue for education or the management of monetary affairs of the company. According to Good (1992), money is looked at as an important factor in the continuity and growth of any organization. It is seen as the lifeblood of the organization on whose existence the organization depends. To him, without funds, the organization ceases to exist because there cannot be any means of facilitating its activities and functions. It enables the organization to achieve its objectives and aims in order to register success and effectiveness. This is in line with equity theory, states supports that when employees perceive the ratios of their inputs (e.g. experience, effort, education e.t.c) to outcomes (rewards) are equivalent to the ratios of other employees then there is existence of equity and employees will work for the success of the organization. But if these ratios are not equivalent, inequity exists and therefore tension is created which may lead to lack of continuity and growth of the organization. As far as financial management in secondary schools is concerned, the latest ground breaking ideas are how to tackle school funding reform. The Georgia proposal uses the federal definition for classroom funding, which includes textbooks, teacher salaries, field trips, and special education as classroom expenses, but excludes "support" funding of speech therapists, librarians, and administrators. Its proponents say the plan is not a punitive measure and that Georgia school districts would have time to achieve the goal. They would be required to increase spending by two percent a year until they reach 65 percent. If the plan is passed, school districts that now meet academic standards and spend less than 65 percent in the classroom would be eligible for a waiver, says Heather Hedrick, a spokeswoman for Governor Perdue.

Nationally, public opinion supports the school reform measure. A Harris Interactive Poll last November showed that 70 to 80 percent of all demographic groups backed the 65 percent solution and the politicians who bring it to the table. "I've never seen an issue this popular," says Tim Mooney, spokesman for First Class Education. "I love it, how the [school superintendents] who are crying most for funding of education are the ones who now say putting dollars in the classroom won't make a difference," he says.

Cash is the money which the organization can distribute immediately without any restriction. The term cash includes coins, currency and cheques balances in the bank counts. Sometimes near cash items such as marketable securities or bank deposits are also included in cash. Financial flow is concerned with managing funds and ensuring that there are always funds to aid the operations of the organisation all the time by monitoring: Cash flows into and out of the organization.

As money plays a vital role in the functioning of any organization, it has to be jealously planned and controlled. It must be used for proper and vital areas, which are to make the organization prosper. Brigham (1995), note that money should not be spent haphazardly by financial controllers but with care, concern and responsibility. In any organization, whether profit- making or non-profit making, funds must not only be maintained but must be made to flow in the right channels. An organization has to establish specific, achievable and widely acceptable goals to which the organization can be financially committed. Goals are needed to provide a basic reference for the allocation of funds. 

DEVELOPMENT

Vol. 7, No. 4, 2018, E-ISSN: 2226-6348 ๑ 2018 HRMARS

Pocock and Taylor 1991 noted that ensuring constant financial flows focuses on financial control whose aim is to obtain the desired financial results through the implementation of plans and using feedbacks to attain the objectives. They further observe that two activities must be put in place to bring about financial control in any organization. These include laying out financial power or duties of financial managers and accountability of the financial resources which necessitates keeping records. While talking about the importance of planning and budgeting, Bottner (1993) argued that, the formal planning system can yield the following to any organization. Plans provide a context for treating together different types of organizational activity; Plans can articulate local priorities and policies for the organization. In the public service and especially in the provision of primary health care, this may have something to do with teams that might be unaware of each other's problems. Plans provide a resource for linking the activities of related organisations; Plans provide a means of managing the public relations or face of the organisations and finally, plans can be resources for juxtaposing and distinguishing the apparent from the real in organizations. Bulman and Deal (1991), comment on the role of plans and budgets as a sign of good management that an organisation must conduct periodically if it wants to maintain its legitimacy. They cite with approval Cohen's (1994) study of planning in schools that identified functions of plans as symbols, as games and as excuses for interaction. According to Button (1998), financial plans and budgets provide an occasion for cultivating values. Theses will include those required by controlling superior organisations. While discussing financial planning and budgeting in large scale organisations, Suchman, (1997) argued that financial planning and budgeting is taken to be any process through which stakeholders in an organisation come together to provide for, or promote the well being of the organisation they serve. The following are intrinsic to this definition; the idea of developing a joint strategic vision for an organisation owned by all stakeholders and a belief that ways must be found to enable stakeholders to participate effectively in the financial plan process. However, Straus (1998) argued that financial planning is involved wherever and whenever people come together in an organization whether big or small and that for purposes of previewing a task and coordinating their activities towards accomplishing it effectively, the meaning and significance of a plan is constructed in use by the members of an organization through ways in which they orient themselves to the plan of action. The importance of funding in school management cannot be over emphasized, ignored or neglected. It is on this note that Stevenson (1991) stressed on the need for funding the school, in many economy such as ours, the service of personnel, the building, the equipment, the supplies and other. Items necessary for the operation of the school system must be paid for; some scholars were of the opinion that if the management of private school is to achieve its desired objectives, quality teachers need to be provided, while their conditions of service are improved as well and all these requires proper funding.

\section{Research Methodology \\ Research design}

The design of this study is a descriptive survey design using structural questionnaire.

\section{Area of the Study}

The study was carried out in all the private secondary schools in Enugu Metropolis of Enugu State. 
INTERNATIONAL JOURNAL OF ACADEMIC RESEARCH IN PROGRESSIVE EDUCATION AND DEVELOPMENT

Vol. 7, No. 4, 2018, E-ISSN: 2226-6348 @ 2018 HRMARS

\section{Population for the Study}

The population for the study comprised of the two hundred and fifty (250) approved private secondary schools presently in Enugu metropolis with about five thousand and thirty (5030) secondary school teachers and one hundred and four (104) principals currently serving in all private secondary schools; (Data from the ministry of Education)

\section{Sample and Sampling Techniques}

Stratified sampling procedures were used in selecting the required sample for this study. Purposive sampling was used in this study in selecting ten schools. Simple random sampling using random number tables was then used to select 500 teachers and 10 principals from the schools. As a result, at Enugu east 4 secondary schools comprising of 190 teachers and 4 principals were selected; at Enugu north 3 secondary schools comprising of 165 teachers and 3 principals were selected; at Enugu south, 3 secondary schools 145 teachers and 3 principals were selected. Thus a total of 10 secondary schools and 500 teachers and 10 principals were sampled. This served as the sample size for the study.

\section{Instrument for Data Collection}

The instrument used for data collection was a structured questionnaire design. This questionnaire consisted of two sections, namely: Section A and B. Section A elicited information on the personal data of the respondent while section $B$ consists of 34 items questionnaire which were drawn from the research question, it was structured for both the teachers and the principal, a four point response scale 4, 3, 2, 1 was used in which they either ticked Strongly agree, Agree, Disagree or Strongly disagree was used. Numerical values were assigned to the options such that SA, A, D, SD since all the 28 items were positive statements. Section B was further divided into 4 clusters.

\section{Validation of the Instrument}

The instrument was subjected to face validation by two experts in the field of educational administration and one expert in the area of measurement and evaluation all from the faculty of Education, Enugu State University of science and technology (ESUT). Clear guidelines on what is expected of them were given. The guidelines includes the purpose of the study, the researcher also requested the experts to critically examine and determine its comprehensiveness, relevance of content, appropriateness of instruction and language use, clarity of statements, possible ambiguities and errors or omissions. A Performa was provided to enable the experts comment on the overall adequacy of the instrument. Based on the experts' comments, one item was dropped and seven others were modified. Thus, their corrections and suggestions were used in modifying the final instrument. This improved the quality of the questionnaire used for the study.

\section{Reliability of the Instrument}

The instruments were taken for piloting on a population that is similar to the target population; it was carried out at Awka which happens to be outside the study area. The piloting included 10 teachers and one head teacher from each of the two schools. The objective of piloting was to allow for modifications of various questions in order to rephrase, clarify and clear up any ambiguities in the questionnaire. Piloting also assisted in testing the reliability of the instruments. 


\section{INTERNATIONAL JOURNAL OF ACADEMIC RESEARCH IN PROGRESSIVE EDUCATION AND}

DEVELOPMENT

Vol. 7, No. 4, 2018, E-ISSN: 2226-6348 @ 2018 HRMARS

In order to measure the internal consistency of the instrument, the Cronbach Alpha reliability estimate was used to analyze the data collected.As a result of the fact that section $B$ is divided into three parts, each treating an aspect of the study, the researcher used tie Cronbach Alpha method of establishing reliability to determine the reliability of each of the three parts of the instrument. The reliability coefficient of parts is 0.92 , part 20.91 , part 30.85 and part 40.88 giving us an overall coefficient of 0.89 these coefficients were regarded as high enough and as a result the instrument is reliable and will actually measure what it purports to measure.

\section{Administration and Retrieval of Instrument}

The researcher with help of 2 trained research assistants distributed 510 questionnaires to the respondent using the face to face distributed techniques. After the collection of the questionnaire from the respondents, 490 were found useful for the study giving us a percentage of 94 , while 20 copies out of the invalid questionnaires were from the teachers.

\section{Method for Data Analysis}

The research questions were answered using mean scores, grand mean and standard deviation. This consideration was appropriate because a four point scale was used to rate the responses of the respondents and were assigned values as follows:

Strongly Agree (SA) (4 Points)

Agree (A) (3 Points)

Disagree (D) (2 Points)

Strongly disagree (SD) (1 Points)

The average for the 4 point rating was 2.50 obtained by adding all the points and dividing by 4 . Thus, $4+3+2+1=10$, then 10 divide by $4=2.50$.

The hypotheses were tested using t-test statistic at .05 level of significance. T-test was used because it could be applied to both large and small samples Uzoagulu (1998).

To interpret the respondent's ratings for the research questions, mean ratings up to and above 2.50 were regarded as 'Agree' while mean scores below 2.50 were regarded as Disagree. For the hypotheses, when the calculated t-value was equal to or more than the critical value, the hypotheses was rejected but when the calculated t- value was less than the critical value, the hypothesis was not rejected.

\section{Data Analysis, Presentation and Interpretation}

Research question 1: To what extent does inadequate funding of private secondary-schools constitute problems to administration?

Table 1: mean response of teachers on the extent of administration problem relating inadequate funding.

\begin{tabular}{|c|c|c|c|c|c|c|c|c|c|}
\hline$S / N$ & QUESTIONNAIRE ITEM & $\begin{array}{r}4 \\
\text { SD }\end{array}$ & $3 \mathrm{~A}$ & $2 \mathrm{D}$ & $\begin{array}{l}1 \\
S D\end{array}$ & TOTAL & $x$ & S.D & REMARKS \\
\hline 1 & $\begin{array}{l}\text { Proprietors sometimes do not fund } \\
\text { private schools properly. }\end{array}$ & 200800 & $\begin{array}{l}250 \\
750\end{array}$ & 4080 & - & $\begin{array}{l}490 \\
1630\end{array}$ & 3.3 & 0.62 & $S A$ \\
\hline
\end{tabular}


INTERNATIONAL JOURNAL OF ACADEMIC RESEARCH IN PROGRESSIVE EDUCATION AND

DEVELOPMENT

Vol. 7, No. 4, 2018, E-ISSN: 2226-6348 @ 2018 HRMARS

\begin{tabular}{|c|c|c|c|c|c|c|c|c|c|}
\hline 2 & $\begin{array}{l}\text { If funded by the proprietors, } \\
\text { principals accused of mismanagement } \\
\text { of such funds }\end{array}$ & $\begin{array}{l}200 \\
800\end{array}$ & $\begin{array}{l}250 \\
750\end{array}$ & $\begin{array}{l}25 \\
50\end{array}$ & $\begin{array}{l}15 \\
15\end{array}$ & $\begin{array}{l}490 \\
1615\end{array}$ & 3.25 & 1.12 & SA \\
\hline 3 & $\begin{array}{l}\text { Principals do not always consider } \\
\text { certain priorities in their expenditure. }\end{array}$ & $\begin{array}{l}180 \\
720\end{array}$ & $\begin{array}{l}280 \\
840\end{array}$ & $\begin{array}{l}10 \\
20\end{array}$ & $\begin{array}{l}20 \\
20\end{array}$ & $\begin{array}{l}490 \\
1600\end{array}$ & 3.26 & 0.71 & SA \\
\hline 4 & $\begin{array}{l}\text { When salaries are not paid as a result } \\
\text { of inadequate funds, the principals and } \\
\text { staff get confused and such } \\
\text { administration is affected. }\end{array}$ & 290 & $\begin{array}{l}200 \\
600\end{array}$ & $\begin{array}{l}40 \\
80\end{array}$ & & $\begin{array}{l}490 \\
1930\end{array}$ & 3.5 & 0.66 & SA \\
\hline 5 & $\begin{array}{l}\text { Principals are sometimes quality of } \\
\text { diverting school funds into their } \\
\text { private pockets or accounts. }\end{array}$ & $\begin{array}{r}300 \\
1200\end{array}$ & $\begin{array}{c}155 \\
465\end{array}$ & $\begin{array}{c}35 \\
70\end{array}$ & - & $\begin{array}{r}490 \\
1735\end{array}$ & 3.95 & 0.56 & SA \\
\hline & Grand mean & & & & & & 3.42 & & \\
\hline
\end{tabular}

KEY: SA - Strongly agree, A- Agree, D - Disagree, SD - Strongly disagree *-mean S.D- Standard Deviation

The above table of responses of respondents indicate that proprietors sometimes do not fund private schools properly with a mean of 3.3 they also agree that salaries are not paid as a result of inadequate funds with mean of $3.25,3.26,3.5$ and 3.95 respectively.

Research question 2: To what extent does the lack of physical facilities constitute problems to administrators of private secondary schools in Enugu Metropolis?

Table 2: Mean responses of respondents on how physical facilities constitute problems to the administration of private secondary schools. 
INTERNATIONAL JOURNAL OF ACADEMIC RESEARCH IN PROGRESSIVE EDUCATION AND

DEVELOPMENT

Vol. 7, No. 4, 2018, E-ISSN: 2226-6348 @ 2018 HRMARS

\begin{tabular}{|c|c|c|c|c|c|c|c|c|c|}
\hline & QUESTIONNAIRE ITEM & $\begin{array}{l}4 \\
S A\end{array}$ & $3 \mathrm{~A}$ & $2 \mathrm{D}$ & $\begin{array}{l}1 \\
\text { SD }\end{array}$ & TOTAL & $x$ & S.D & $\begin{array}{l}\text { REM } \\
\text { ARKS }\end{array}$ \\
\hline 6 & $\begin{array}{l}\text { Inadequate facilities sometimes } \\
\text { hinder the management in } \\
\text { performing their respective } \\
\text { duties.. }\end{array}$ & $\begin{array}{l}240 \\
960\end{array}$ & $\begin{array}{l}250 \\
750\end{array}$ & & & $\begin{array}{l}490 \\
1710\end{array}$ & 3.4 & 0.51 & SA \\
\hline 7 & $\begin{array}{l}\text { The size of the school } \\
\text { environment affects adversely } \\
\text { management effectiveness.. }\end{array}$ & $\begin{array}{c}245 \\
980\end{array}$ & $\begin{array}{l}235 \\
705\end{array}$ & $\begin{array}{c}10 \\
20\end{array}$ & $\begin{array}{l}41 \\
41\end{array}$ & $\begin{array}{l}490 \\
1705\end{array}$ & 3.55 & 0.54 & SA \\
\hline 8 & $\begin{array}{l}\text { Proprietors of } r \text { private } \\
\text { secondary } \\
\text { schools don't put } \\
\text { school facilities }\end{array}$ & $\begin{array}{l}275 \\
1100\end{array}$ & $\begin{array}{c}204 \\
612\end{array}$ & 1122 & & $\begin{array}{l}490 \\
1734\end{array}$ & 3.62 & 0.55 & SA \\
\hline 9 & $\begin{array}{l}\text { The availability of space } \\
\text { determines the output of the } \\
\text { management of school } \\
\text { personnel. }\end{array}$ & $\begin{array}{l}420 \\
1680\end{array}$ & $\begin{array}{l}70 \\
210\end{array}$ & & & $\begin{array}{l}490 \\
1890\end{array}$ & 3.9 & 0.35 & SA \\
\hline & Grand mean & & & & & & 3.64 & & \\
\hline
\end{tabular}

KEY: SA - Strongly agree, A- Agree, D - Disagree, SD - Strongly disagree mean S.D- Standard Deviation

From the above table teachers agreed that inadequate physical facility of a private secondary school could constitute problems to the administration of schools with a mean score of 3.64. They also agree that the availability of space determines the output of the management and that sometimes proprietors of private secondary schools don't put school facilities into consideration with mean scores of 3.9 and 3.62 respectively. They also agreed that the size of the school environment affect adversely the management effectiveness with a mean score of 3.55.

\section{Test of Hypothesis}

\section{Research Hypothesis 1}

$\mathrm{Ho}_{1}$ - significant difference does not exist between the mean responses of principals and teachers on whether inadequate funding of private secondary schools constitutes problems to school management in Enugu Metropolis. 
INTERNATIONAL JOURNAL OF ACADEMIC RESEARCH IN PROGRESSIVE EDUCATION AND DEVELOPMENT

Vol. 7, No. 4, 2018, E-ISSN: 2226-6348 @ 2018 HRMARS

Table 3: t-test result of the mean responses of respondents on the problems of funding to the management in Enugu Metropolis.

\begin{tabular}{|l|l|l|l|l|l|l|l|}
\hline Staffs & $x$ & $\mathrm{~N}$ & $\mathrm{~S}^{2}$ & $\mathrm{df}$ & $\mathrm{t}$-cal & $\mathrm{t}$-tab & Decision \\
\hline Principals & 2.04 & 10 & 0.734 & 488 & 1.93 & \pm 1.96 & $\begin{array}{l}\text { Do not } \\
\text { reject } \\
\mathrm{Ho}_{1}\end{array}$ \\
\hline
\end{tabular}

The t-table analysis in table 3 above indicates that the calculated t-value is 1.93 while the $t$-value is \pm 1.96 at 0.05 level of significance. This implies that the calculated t-value is less than the critical $t$ value. Thus, there is no significant difference between the mean responses of principals and teachers on whether inadequate funding of private secondary schools constitutes problems to school management in Enugu Metropolis.

\section{Research Hypothesis 2}

$\mathrm{HO}_{2}$ : Significant difference does not exist between the mean responses of principals and teachers on the contribution of physical facilities and the management of private secondary schools.

Table 4: t-test result of the mean responses of respondents on the contribution of physical facilities and the management of private secondary schools

\begin{tabular}{|l|l|l|l|l|l|l|l|}
\hline Staffs & $x$ & $\mathrm{~N}$ & $\mathrm{~S}^{2}$ & $\mathrm{df}$ & $\mathrm{t}$-cal & l-tab & Decision \\
\hline Principals & 2.47 & 10 & 0.488 & 488 & 1.14 & \pm 1.96 & $\begin{array}{l}\text { Do not reject } \\
\text { Hq4 }\end{array}$ \\
\hline Teachers & 4.81 & 480 & & & & & \\
\hline
\end{tabular}

The t-table analysis in table 4 above indicates that the calculated t-value is 1.14 while the t-value is \pm 1.96 at 0.05 level of significance. This implies that the calculated $t$-value is less than the critical $t$ value. Thus, there is no significant difference in the mean responses of principals and teachers on the contribution of physical facilities and the management of private secondary schools.

\section{Discussion of Findings}

Based on the finding of research question one which investigated on the funding of private secondary school, it agreed that inadequate funding of private secondary schools bring along with it improper administration of private secondary schools in Enugu metropolis. This is because lack of fund generates liassez-fair, nonchalant and lack of co-operation among the staff hence 
Vol. 7, No. 4, 2018, E-ISSN: 2226-6348 @ 2018 HRMARS

making it very difficult for the organizational goals to be achieved. It is on this basis that Adesina and Ogunsaya (1984) stressed that: the success of secondary school depends upon the resources available to it. Money is very essential in this respect because by it all other vital elements in the school can be obtained such as payment of teachers salaries and allowances, school building, purchase of equipment and running expenses, poor funding can also result to lack of infrastructure and equipment. Lack of classroom accommodation forces the teachers to teach under unhealthy environment and this affects teaching and learning. Lack of equipment and textbooks frustrates both teachers and students. With adequate findings, skilled and quality teachers should be recruited for a positive change.

Furthermore, the second research question sought answers to what extent does lack of physical facilities constitute problems to administrators in Enugu metropolis. From analysis above we can deduce that private schools are often less concerned with their environment as they tend to start school in any available space within their reach which sometimes constitute problems to administrators in Enugu metropolis. This is in line with the earlier findings of Jamil (1992). He found that school administrators in Ogun state often seek the availability of students not availability of space before starting private secondary schools and it latter affect the entire school.

\section{Summary of Findings}

In summary, based on the analysis of the data generated in this study the following findings were made:-

1. No organization can function effectively when it is not properly funded; finance is the life-blood of any organization. It is the finance that is used in paying the teachers' salaries and running of the school. The studies revealed that lack of funds in private secondary schools contribute immensely to the failure of managers.

2. Furthermore, lack of conducive learning environment due to inadequate physical facilities constitute problems to the administrators in Enugu metropolis, this is due to the increasing population of children in the metropolis and also parents tend to believe that their children are not properly educated in public schools.

\section{Conclusion}

Form all the information gathered based on the major findings from the study. The following conclusions were made:-

The inadequate funding of private schools prevalent problems that hinders proper administration of private schools in Enugu metropolis must be handled in order to prevent collapse of the institution and the private schools going out of business. Finally there are essential physical facilities needed for the proper and effective running of private secondary schools in Enugu metropolis and they must be acquired and properly installed for business to continue.

\section{Recommendation}

Based on the findings of the study the following recommendations were made:-

1. That the inadequate funding of private secondary school which is one of the hindrances of proper administration should be eradicated through collective efforts of the community government and the parents. 


\section{INTERNATIONAL JOURNAL OF ACADEMIC RESEARCH IN PROGRESSIVE EDUCATION AND DEVELOPMENT}

Vol. 7, No. 4, 2018, E-ISSN: 2226-6348 @ 2018 HRMARS

2. That the educational planners should try to plan for private secondary school by considering the level of physical facilities that should accommodate the needs and aspirations of the population of enrollment at that certain time through knowing the actual statistics of the pupils in primary schools who will be going to be posted to schools.

\section{References}

Adesina, O.M. (2011). Education is a major force in economic, intellectual, social and cultural empowerment. Jos: challenge.

Belfied, D.N. and Levin, C.E. (2003). The role of parents in the financing of education private ownership of the funding and management of schools. New York; Free press

Good, F. R. (1992). Money is looked at as an important factor in the continuity and growth of any organization.

Moshin, W.S. (1999) defines finance for education as the science and practice of raising and expending of revenue for education or the management of monetary affairs of the company. 